\title{
S33: Prolyl aminopeptidase (version 2019.4) in the IUPHAR/BPS Guide to Pharmacology Database
}

\author{
1. University of Nottingham, UK \\ 2. King's College London, UK \\ 3. University Hospital of Umeå, Sweden
}

Stephen P.H. Alexander ${ }^{1}$, Patrick Doherty ${ }^{2}$ and Christopher J. Fowler ${ }^{3}$

\begin{abstract}
Peptidase family S33 contains mainly exopeptidases that act at the $\mathrm{N}$-terminus of peptides.
\end{abstract}

\section{Contents}

This is a citation summary for S33: Prolyl aminopeptidase in the Guide to Pharmacology database (GtoPdb). It exists purely as an adjunct to the database to facilitate the recognition of citations to and from the database by citation analyzers. Readers will almost certainly want to visit the relevant sections of the database which are given here under database links.

GtoPdb is an expert-driven guide to pharmacological targets and the substances that act on them. GtoPdb is a reference work which is most usefully represented as an on-line database. As in any publication this work should be appropriately cited, and the papers it cites should also be recognized. This document provides a citation for the relevant parts of the database, and also provides a reference list for the research cited by those parts.

Please note that the database version for the citations given in GtoPdb are to the most recent preceding version in which the family or its subfamilies and targets were substantially changed. The links below are to the current version. If you need to consult the cited version, rather than the most recent version, please contact the GtoPdb curators.

\section{Database links}

S33: Prolyl aminopeptidase

http://www.guidetopharmacology.org/GRAC/FamilyDisplayForward?familyld=917

Enzymes

lipase, gastric

http://www.guidetopharmacology.org/GRAC/ObjectDisplayForward?objectld=2626

protein phosphatase methylesterase 1

http://www.guidetopharmacology.org/GRAC/ObjectDisplayForward?objectld=2875

MAGL(Monoacylglycerol lipase)

http://www.guidetopharmacology.org/GRAC/ObjectDisplayForward?objectld=1399 


\section{References}

1. Aaltonen N, Savinainen JR, Ribas CR, Rönkkö J, Kuusisto A, Korhonen J, Navia-Paldanius D, Häyrinen J, Takabe P and Käsnänen $\mathrm{H}$ et al.. (2013) Piperazine and piperidine triazole ureas as ultrapotent and highly selective inhibitors of monoacylglycerol lipase. Chem. Biol. 20: 379-90 [PMID:23521796]

2. Bachovchin DA, Koblan LW, Wu W, Liu Y, Li Y, Zhao P, Woznica I, Shu Y, Lai JH and Poplawski SEet al.. (2014) A high-throughput, multiplexed assay for superfamily-wide profiling of enzyme activity. Nat. Chem. Biol. 10: 656-63 [PMID:24997602]

3. Chang JW, Niphakis MJ, Lum KM, Cognetta 3rd AB, Wang C, Matthews ML, Niessen S, Buczynski MW, Parsons LH and Cravatt BF. (2012) Highly selective inhibitors of monoacylglycerol lipase bearing a reactive group that is bioisosteric with endocannabinoid substrates. Chem. Biol. 19: 579-88 [PMID:22542104]

4. Cisar JS, Weber OD, Clapper JR, Blankman JL, Henry CL, Simon GM, Alexander JP, Jones TK, Ezekowitz RAB and O'Neill GP et al.. (2018) Identification of ABX-1431, a Selective Inhibitor of Monoacylglycerol Lipase and Clinical Candidate for Treatment of Neurological Disorders. J. Med. Chem. 61: 9062-9084 [PMID:30067909]

5. Ghafouri N, Tiger G, Razdan RK, Mahadevan A, Pertwee RG, Martin BR and Fowler CJ. (2004) Inhibition of monoacylglycerol lipase and fatty acid amide hydrolase by analogues of 2-arachidonoylglycerol. Br. J. Pharmacol. 143: 774-84 [PMID:15492019]

6. Long JZ, Li W, Booker L, Burston JJ, Kinsey SG, Schlosburg JE, Pavón FJ, Serrano AM, Selley DE and Parsons LH et al.. (2009) Selective blockade of 2-arachidonoylglycerol hydrolysis produces cannabinoid behavioral effects. Nat. Chem. Biol. 5: 37-44 [PMID:19029917]

7. Long JZ, Nomura DK, Vann RE, Walentiny DM, Booker L, Jin X, Burston JJ, Sim-Selley LJ, Lichtman AH and Wiley JL et al.. (2009) Dual blockade of FAAH and MAGL identifies behavioral processes regulated by endocannabinoid crosstalk in vivo. Proc. Natl. Acad. Sci. U.S.A. 106: 20270-5 [PMID:19918051]

8. Niphakis MJ, Cognetta 3rd AB, Chang JW, Buczynski MW, Parsons LH, Byrne F, Burston JJ, Chapman V and Cravatt BF. (2013) Evaluation of NHS carbamates as a potent and selective class of endocannabinoid hydrolase inhibitors. ACS Chem Neurosci 4: 1322-32 [PMID:23731016] 